\title{
Non-linear behavior of innovative steel cable-stayed bridge stiffening girder
}

\author{
Modestas Stragys \\ Department of Steel and Composite Structures, Vilnius Gediminas Technical University, Vilnius, Lithuania
}

\author{
E-mail: modestas.stragys@gmail.com
}

\begin{abstract}
Until these days there are three very well-known structural forms in cable-stayed bridge construction: radial, harp and fan. These three well-known and analyzed systems ensure the stability of the cable-stayed bridges in a variety of conditions. In order to reduce the amount of materials various solutions are used. One way to reduce the cost of steel may be a new, innovative structural form. A new cable-stayed bridge structure, which requires smaller quantities of materials, is proposed in this Paper. New structural form is compared with traditional cable-stayed structures and the conclusions, which reflect the advantages of this construction, are presented. Result of the analysis is evaluation of innovative cable-stayed structure bending moments, axial forces, deflections and non-linear behavior compared with traditional cable-stayed structure under the influence of both symmetric as asymmetric loads. Technical-economical assessment is also proposed in the Paper. The Paper gives an overview of the differences between traditional and innovative design of cable-stayed bridges.
\end{abstract}

Keywords: new form, cable behavior, cable junction, cable coordinate, comparison analysis, technical-economical assessment, advantages and disadvantages.

\section{Introduction}

As the new era of cable-stayed bridges started, architects and engineers sought to find new forms and interesting construction schemes. Great attention was paid to the aesthetics of bridges and to the adaptation to the environment. Eyepleasing proportions were very important and the first one to notice them in $571-497$ B.C. was Greek philosopher Pythagoras. He said that proportions between small integers $(1: 2,2: 3,3: 4,4: 3$, or 3:2) have a long-lasting effect. This is true for painting, music, and for all other types of art (Szabo, 1969). The success of the steel cable-stayed bridges began with the creation of an orthotropic overlay plate. Until the Second World War, individual bridge elements acted independently of each other, but this situation changed with the appearance of orthotropic plates, and after the construction of the Strömsund steel cable-stayed bridge, the real era of cable-stayed bridges began (Svensson, 2012).

Due to their esthetic appearance, efficient utilization of structural materials and other notable advantages, cablestayed bridges have been recognized as the most appealing structures and have gained much popularity in recent decades (Thai \& Kim, 2012).

Cable-stayed bridge is one of most difficult bridge constructions. There are many parameters that are important in the design phase of such bridges. One of those parameters is nonlinear behavior, which has great importance in cable-stayed bridge construction.

A cable-stayed bridge is a nonlinear structural system in which the girder is supported elastically at points along its length by inclined cable stays. Although the behavior of the material is linearly elastic, the overall load-displacement response may be nonlinear under normal design loads (Fleming, 1979; Nazmy \& Abdel-Ghaffar, 1990; Abdel Raheem \& Hayashikawa, 2003).

There are three main sources of geometrically nonlinear behavior of cable-stayed bridges: the beam-column effect, the large displacements (known as P-D) effect and the cable sag effect. All three sources affect behavior of stiffening girder of cable-stayed bridge. Depending on type of the cable-stayed bridge some of nonlinearities are more expressed than another.

Though some sources of materially nonlinear behavior, such as layered bearings or special seismic devices, may have to be considered in the analysis, most nonlinear responses of steel cable-stayed bridges have their origin in geometric causes (Freire, Negrão, \& Lopes, 2006).

(C) 2019 Authors. Published by VGTU Press. This is an open-access article distributed under the terms of the Creative Commons Attribution (http://creativecommons.org/licenses/by/4.0/) License, which permits unrestricted use, distribution, and reproduction in any medium, provided the original author and source are credited. 
Until these days there are three well-known stuctural forms of cable-stayed bridges: radial, fan and harp (Podolny, 2011; Gimsing \& Georgakis, 2012). These very well-known and analysed forms ensured stability of cable stayed bridges in various conditions. Nevertheless, great importance in cable-stayed design has technical-economical evaluation. Engineers are trying to ensure lower material costs using many different solutions.

New structural form of cable stayed bridges is proposed in this Paper. Importance of nonlinear assessment is given and nonlinear behavior forms of new structure cable-stayed bridge are presented. The Paper gives an overview of nonlinear assessment of new structural form of cable-stayed bridges. New form is compared to traditional cablestayed bridges and conclusions regarding nonlinear behavior and technical-economical assessment are made.

\section{New structural form of cable-stayed bridges}

One of the options to reduce steel consumption for cable-stayed bridge construction is new, innovative structural form. This form (see Figure 1) ensures $25 \%$ or even more reduced steel consumption in cable-stayed bridge construction.

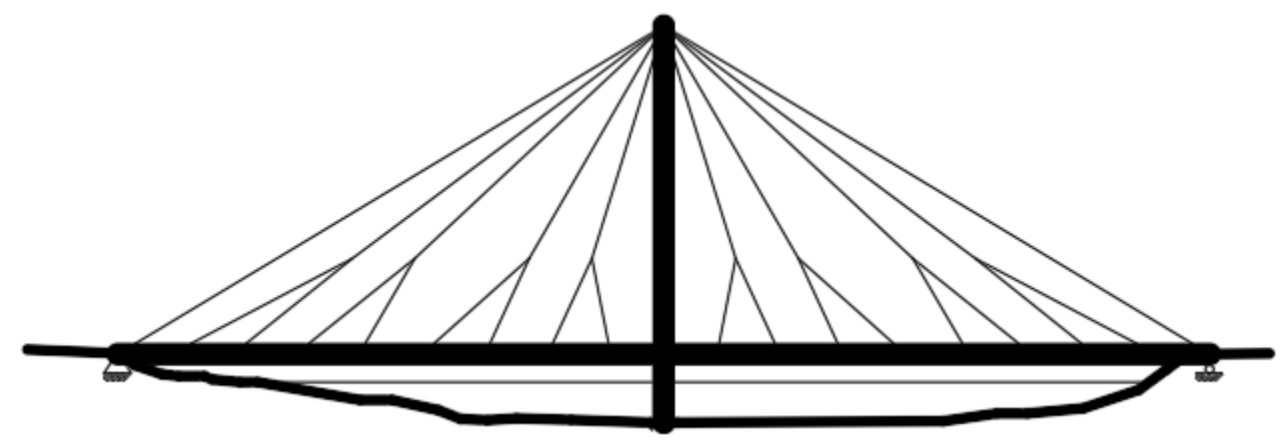

Figure 1. Innovative cable-stayed bridge

As seen in the picture above, main difference, in comparison with traditional cable-stayed bridges, is cable arrangement. This two-level branched arrangement brings reduced steel consumption and allows to use cable-stayed construction for longer spans, however, makes stress regulations in stiffening girder and construction stage more difficult. In this Paper non-linear behavior of stiffening girder in such bridges is analyzed under certain circumstances:

- Non-linear cable behavior approach.

- Different coordinates of cables junction approach. structure.

To estimate real difference, traditional cable-stayed bridge (see Figure 2) is analyzed in comparison with this new

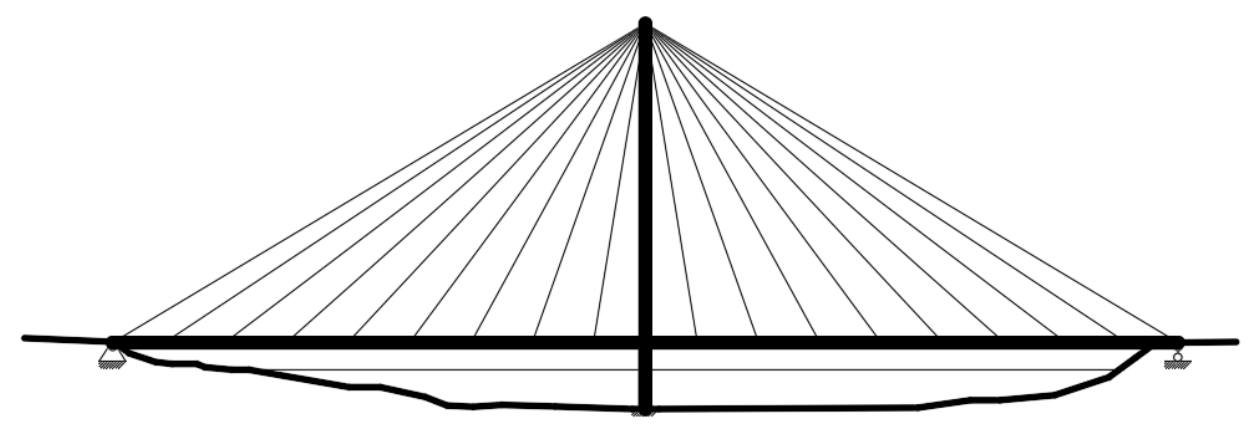

Figure 2. Traditional cable-stayed bridge

\section{Non-linear behaviour analysis of stiffening girder}

To compare two different cable-stayed bridges, span of 40 meters was considered. For this span two types of bridges were selected: first one is traditional radial cable-stayed bridge (see Figure 2), second one - innovative cable-stayed bridge (see Figure 1).

Both bridges are affected by same symmetric and asymmetric loads. Symmetric load is distributed along whole span length. Asymmetric load affects only distance between the beginning of stiffening girder and the pylon.

Non-linear behavior of stiffening girder is the main goal of this analysis. First, it is proven that non-linear calculations for cable-stayed bridges are mandatory. Then, main feature of innovative cable-stayed form is analyzed in terms of non-linear analysis in stiffening girder. 


\section{Non-linear cable behavior approach}

Each part of the stiffening girder between cables have its own displacement $\Delta \mathrm{u}$ and different slenderness coefficient $k l$ - see Eq. (1) below. Difference and importance between linear and non-linear stiffening girder behavior can be estimated analyzing the difference between bending moments $\Delta \mathrm{M}$ while calculating different stiffening girder parts with different $\mathrm{kl}$ and $\Delta \mathrm{u}$ parameters (see Figure 3).

$$
k l=l_{b i} \sqrt{\frac{N_{c i}}{E_{i} I_{i}}},
$$

where: $k l$-slenderness ratio of stiffening girder; $l_{b i}$ - length of stiffening girder; $N_{c i}-$ axial force in the stiffening girder; $E_{i} I_{i}$ - flexural rigidity of stiffening girder.

First $\Delta \mathrm{M}$ jump can be seen when $\mathrm{kl}$ value reaches 1.2 . From this point it gets irrational to use linear calculation methods for cable-cable stayed bridges. From value 1.6 significant increase of $\Delta M$ is seen. This happens because of cable sag effect.

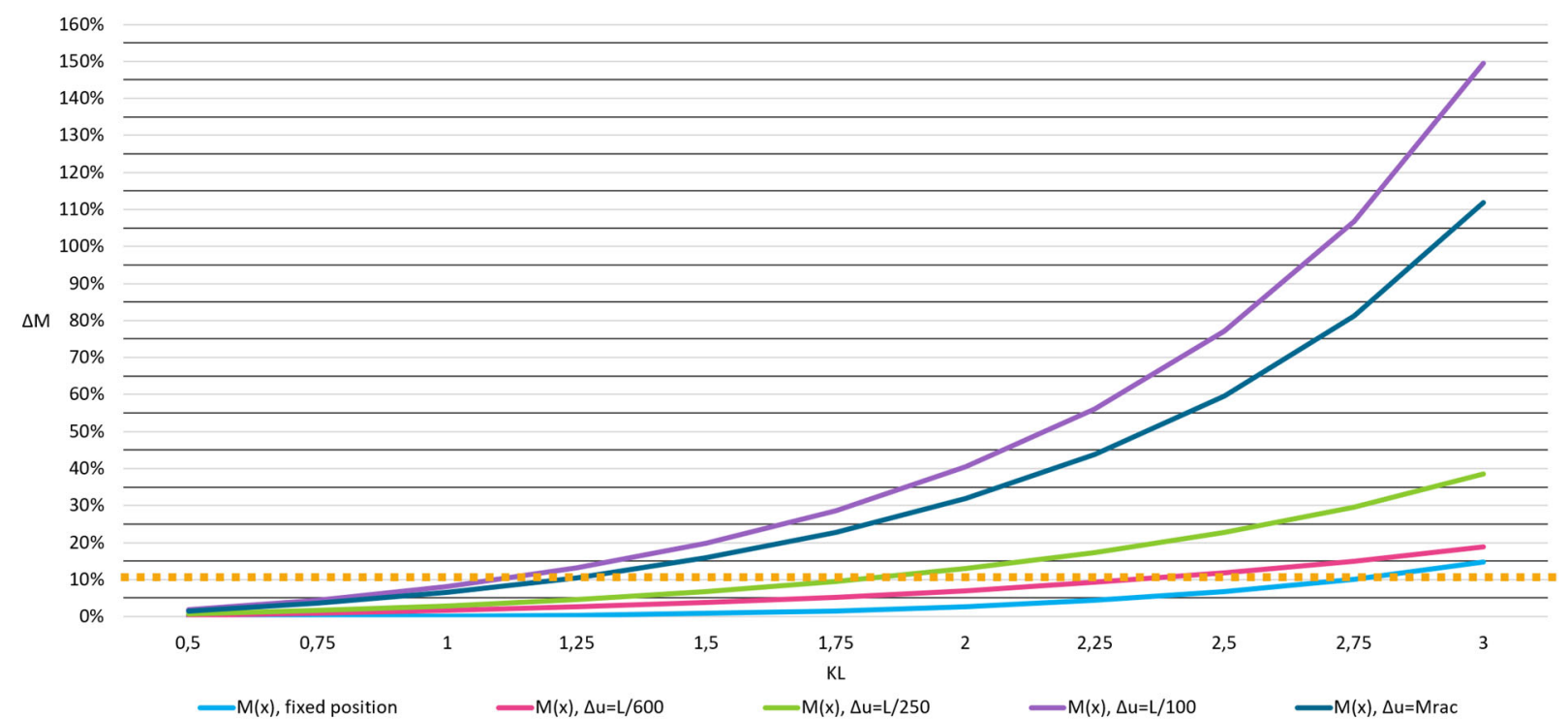

Figure 3. Difference between linear and non-linear behavior in cable-stayed bridge stiffening girder

When cable is fixed at both ends, it sags because of axial force and its own weight. The axial stiffness of the cable depends on the displacement of its ends, which occurs due to material deformation and cable inclination. As the axial force increases, the sag decreases, and the displacement of the cable ends remains practically only due to material deformations. Also, as the axial force increases, the tensile stresses are also increasing. This behavior of the cable can be calculated in two ways. Simplified - if the cable takes over only the tensile stresses and is completely straightforward. In this case, non-linearity is evaluated by introducing an equivalent modulus of elasticity, which depends on the acting force and the weight of the cable. The second method of calculation is much more complicated and estimates how the cable with initial sag works (Thai \& Kim, 2012; Wang, Tseng, \& Yang, 1993; Hajdin, Michaltsos, \& Konstantakopoulos, 1998; Freire et al., 2006; Baldomir, Hernandez, Nieto, \& Jurado, 2010). The first two people who talked about the importance of the equivalent modulus of elasticity were F. Dischinger (1949), who later delivered a tangential equivalent modulus of elasticity, and H. Ernst (1965), who later gave a matrix equivalent modulus of elasticity.

Because of these reasons non-linear assessment in cable-stayed bridge calculation in mandatory.

\section{Different coordinates of cable junction approach}

Normally there are two methods for optimizing bending moments in cable-stayed bridge stiffening girder. First one is optimization of cross-section of the cable, second one is pretension forces in cables. Using both methods it is possible to reach nearly rational bending moments. New structure has additional parameter to these two - cables junction coordinate. Exact coordinate of cables junction in space can be crucial for rational bending moments in stiffening girder as also for displacements of different points in construction.

To evaluate importance of correct branched cable junction coordinates many different simple schemes are analyzed (see Figure 4). 

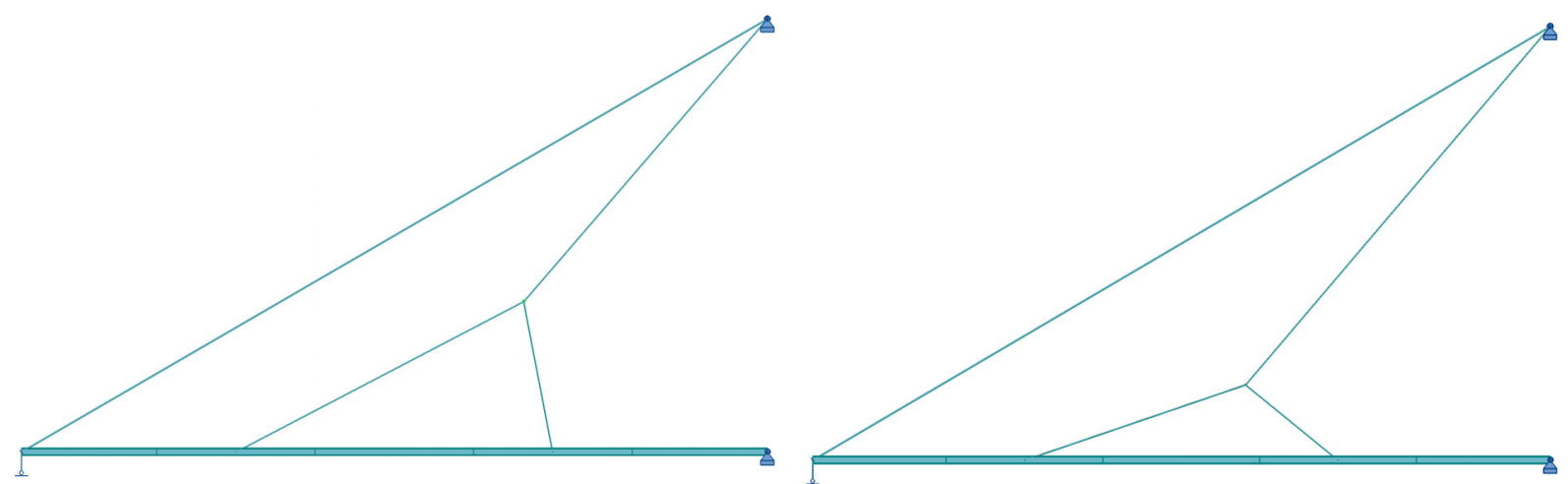

Figure 4. Different analyzed schemes of cables junction coordinates

Analysis is made when the height of cables junction $\mathrm{Hj}$ is from 0.1 up to 0.8 of the height of the whole pylon $\mathrm{H}$. For each height few different calculations are made when $\mathrm{x}$ coordinate of cables junction varies from the perfect value, which is needed to reach rational bending moments, up to $10 \%$ away from that value. Results can be seen in Table 1 for bending moments and Table 2 for displacements.

Table 1. Difference of bending moments in stiffening girder when cables junction coordinates are wrong

\begin{tabular}{|c|c|c|c|c|c|}
\hline \multicolumn{5}{|c|}{ Bending Moments difference in Stiffening Girder, \% } \\
\hline$H_{J} / x$ & 1 & 0.99 & 0.98 & 0.95 & 0.9 \\
\hline $0.1 H$ & $0 \%$ & $6 \%$ & $15 \%$ & $34 \%$ & $51 \%$ \\
\hline $0.2 H$ & $0 \%$ & $12 \%$ & $21 \%$ & $39 \%$ & $55 \%$ \\
\hline $0.4 H$ & $0 \%$ & $15 \%$ & $27 \%$ & $47 \%$ & $45 \%$ \\
\hline $0.6 H$ & $0 \%$ & $22 \%$ & $36 \%$ & $57 \%$ & $70 \%$ \\
\hline $0.8 H$ & $0 \%$ & $33 \%$ & $49 \%$ & $67 \%$ & $78 \%$ \\
\hline
\end{tabular}

Table 2. Difference of displacements in stiffening girder when cables junction coordinates are wrong

\begin{tabular}{|c|c|c|c|c|c|}
\hline \multicolumn{6}{|c|}{ Displacements difference in Stiffening Girder, $\%$} \\
\hline$H_{J} / x$ & 1 & 0.99 & 0.98 & 0.95 & 0.9 \\
\hline $0.1 H$ & $0 \%$ & $0 \%$ & $1 \%$ & $8 \%$ & $28 \%$ \\
\hline $0.2 H$ & $0 \%$ & $0 \%$ & $4 \%$ & $22 \%$ & $49 \%$ \\
\hline $0.4 H$ & $0 \%$ & $0 \%$ & $8 \%$ & $40 \%$ & $37 \%$ \\
\hline $0.6 H$ & $0 \%$ & $7 \%$ & $23 \%$ & $63 \%$ & $84 \%$ \\
\hline $0.8 H$ & $0 \%$ & $19 \%$ & $49 \%$ & $82 \%$ & $93 \%$ \\
\hline
\end{tabular}

\section{Technical-economical assesment}

One of the most significant indicators in the construction of bridges is their economic efficiency. The solutions for reducing the costs of construction work and materials are constantly under consideration. The branched cable-stayed bridge helps save up to 34\% of steel (see Figure 5). Most importantly, the branched cable-stayed bridges require as much as $20 \%$ less steel than the standard cable-stayed bridges. In the context of modern construction this indicator is very important while calculating the economic efficiency of bridge construction (Stragys, 2019).

The highly effective control of stresses in the stiffening girder under asymmetric loads, the lesser amount of cables with their denser distribution and the uneven distribution of axial forces are the main reasons proving that a branched cable-stayed bridge is more cost-effective than the conventional cable-stayed bridges. Figure 5 shows that up to $50 \%$ less steel is used for the stiffening girder, $39 \%$ less steel for the pylons and $20 \%$ less steel for the stay cables. Such results are achieved in the comparison of the $80 \mathrm{~m}$ span two-level branched cable-stayed bridge with a conventional fan bridge of the same span. In case of the increase of the span the cross-sections of all three elements grow. In other words, as the span grows, the economic efficiency of the two-level branched cable-stayed bridges is increasing even more (Stragys, 2019). 


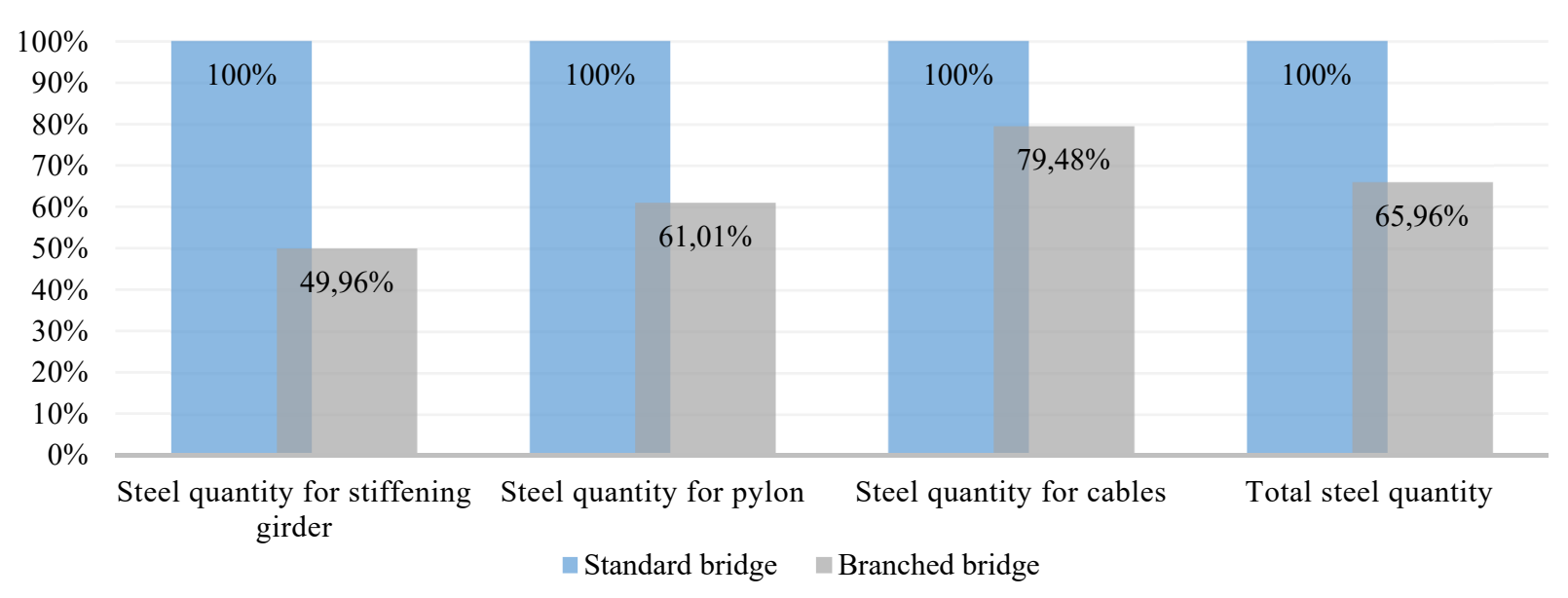

Figure 5. Technical-economical assessment of innovative steel cable-stayed bridge

\section{Conclusions}

With the rapid development of bridge construction technologies and the need for large spans, the search is on for new solutions that would deal not only with the structural but also the cost-effective implementation. One of the new and extremely promising systems is the branched cable-stayed bridges. The analysis of the deformed state behaviour of these bridges leads to the conclusion that this system can be one of the main cable-stayed bridge systems in pursuit of increasing the bridge spans up to record lengths.

The branched cable-stayed bridge structure allows to manage the asymmetric loads effectively which is an important indicator for reducing the cross-sections of the bridge elements. Such structure requires a lesser amount of cables. Designing such a structure is a complicated process, however, the development of a proper calculation methodology and practical recommendations can make this cable-stayed bridge structure one of the most promising (Stragys, 2018).

The study of the behaviour of the two-level branched cable-stayed bridge led to several main conclusions:

- It is necessary to evaluate non-linear behaviour in cable-stayed bridge stiffening girder. While it is not significant difference between linear and non-linear calculations in stiffening girder up to 1.2 slenderness ratio or low displacements, it is high difference when stiffening girder is calculated to reach rational bending moments.

- It is necessary to calculate right cable junction positions. Slight difference in $\mathrm{x}$ coordinate value can cause big differences in cable-stayed bridge stiffening girder bending moments and displacements.

- Innovative cable-stayed bridge structure can save up to $35 \%$ of steel material for construction. This is mainly because of good control of bending moment in stiffening girder under the presence of asymmetrical loads.

\section{References}

Abdel Raheem, S. E., \& Hayashikawa, T. (2003). Parametric study on steel tower seismic response of cable-stayed bridges under great earthquake ground motion. Structural Engineering and Earthquake Engineering, JSCE, 20(1), 25-41. https://doi.org/10.2208/jsceseee.20.25s

Baldomir, A., Hernandez, S., Nieto, F., \& Jurado, J. A. (2010). Cable optimization of a long span cable stayed bridge in La Coruna (Spain). Advances in Engineering Software, 41(7-8), 931-938. https://doi.org/10.1016/j.advengsoft.2010.05.001

Dischinger, F. (1949). Hängebrücken für Schwerste Verkehrslasten. Der Bauingenieur, 24 (März und April).

Ernst, H. J. (1965). Der E-Modul von Seilen unter Brücksichtigung des Durchhängers. Bauingenieur 40, Heft 2, 52-55.

Fleming, J. F. (1979). Nonlinear static analysis of cable-stayed bridge structures. Computers and Structures, 10(4), 621-635. https://doi.org/10.1016/0045-7949(79)90006-3

Freire, A. M. S., Negrão, J. H. O., \& Lopes, A. V. (2006). Geometrical nonlinearities on the static analysis of highly flexible steel cable-stayed bridges. Computers \& Structures, 84(31-32), 2128-2140. https://doi.org/10.1016/j.compstruc.2006.08.047

Gimsing, N. J., \& Georgakis, C. T. (2012). Cable supported bridges: Concept and design (Third ed.). https://doi.org/10.1002/9781119978237

Hajdin, N., Michaltsos, G. T., \& Konstantakopoulos, T. G. (1998). About the equivalent modulus of elasticity of cables of cablestayed bridges. Facta Universitatis, 1(5), 569-575.

Nazmy, A. S., \& Abdel-Ghaffar, A. M. (1990). Three-dimensional nonlinear static analysis of cable-stayed bridges. Computers \& Structures, 34(2), 257-271. https://doi.org/10.1016/0045-7949(90)90369-D 
Podolny, W. (2011). Cable-suspended bridges. In Structural steel designer's handbook (5 ${ }^{\text {th }}$ ed.). By R. L. Brockenbrough \& F. S. Merritt. McGraw-Hill, New York.

Stragys, M. (2018). Inovatyvaus šakotinio plieninio vantinio pėsčiųjų tilto lyginamoji analizè. Iš Mokslas - Lietuvos ateitis / Science - Future of Lithuania, 10, 1-7. https://doi.org/10.3846/mla.2018.6260

Stragys, M. (2019). The preliminary design and technical-economic efficiency of the two-level branched cable-stayed bridge. Engineering Structures and Technologies, 11(1), 17-24.https://doi.org/10.3846/est.2019.8858

Svensson, H. (2012). Cable-stayed bridges: 40 Years of experience worldwide. John Wiley \& Sons, Inc. https://doi.org/10.1002/9783433601044

Szabo, I. (1969). Anfänge der griechischen Mathematik. Oldenbourg Wissenschaftsverlag. https://doi.org/10.1515/9783486819861

Thai, H.-T., \& Kim, S.-E. (2012). Second-order inelastic analysis of cable-stayed bridges. Finite Elements in Analysis and Design, 53, 48-55. https://doi.org/10.1016/j.finel.2011.07.002

Wang, P. H., Tseng, T. C., \& Yang, C. G. (1993). Initial shape of cable stayed bridge. Computers \& Structures, 47(1), $111-123$. https://doi.org/10.1016/0045-7949(93)90284-K 